\title{
PENDIDIKAN KARAKTER KEWIRAUSAHAAN: STUDI NILAI SPIRITUAL ISLAM BERDASARKAN TAFSIR TARBAWI QS. ALI IMRON : 200
}

\author{
Abstract \\ Oleh: \\ The world, lately, has experienced various challenges, both from technological \\ Irfan Afandi \\ developments, disasters and pandemic diseases. However, buman life must continue to \\ run as it should with various creative efforts. For the purpose of creating creative \\ entrepreneurship, character education is needed. One of them is sourced in Qs. Ali Imron: \\ Email: \\ 200 where this verse teaches four spiritual values namely patience level 1 \& 2 , ribath \\ and taqwa. This spiritual value can be tanght with a pattern of character education with \\ Irfan.edu26@gmail.com \\ an integrative learning model. This allows the delivery of four spiritual values contained \\ in the verse. Integrative learning patterns that can be applied include the first, \\ interdisciplinary patterns in which learning how to integrate a concept of skills or abilities \\ Institut Agama Islam Ibr \\ ahimy Genteng, \\ that are grown and developed in one subject or sub-topic in one field of study; second, \\ interdisciplinary learning where learning is carried out by combining fields of study by \\ Banyuwangi \\ finding the same concepts, skills, and attitudes as the four moral values.
}

Keywords: Character Education, Sabr, Ribath, Religious, Entrepreneurship

\section{PENDAHULUAN}

Perubahan teknologi, iklim, demografi dan budaya terjadi semakin cepat dan semakin masif dalam kehidupan global manusia. Perubahan ini membawa pengaruh di segenap aspek kehidupan salah satunya di dunia usaha atau berwirausaha. Seringkali ketika seseorang akan memulai berwirausaha, ide dan gagasan terlihat begitu baik dan memiliki peluang yang lebar; tetapi sebenarnya inu merupakan awal dari masalah. Postulat yang bisa dirumuskan dalam dunia wirausaha adalah bahwa tantangan dan halangan akan datang kepada mereka yang sedang berjuang dan berusaha.

Dunia wirausaha pada saat ini memiliki tantangan berupa badai' perkembangan teknologi (tech storm) yang mampu membuat artifisial intelegent

\footnotetext{
1 Irfan Afandi and M Amir Mahmud, "STRATEGI MENGHADAPI COBAAN DALAM AL-QUR'AN (Pemaknaan Tekstual Dan Kontekstual Terhadap Qs. Al-
}

di mana kecerdasan buatan mengambil alih hampir segala sisi manusia. Hal ini diperparah dengan adanya 'badai' biologis (bio storm) yang berupa penyebaran virus korona yang dikenal dengan sebutan Covid-19 yang menyebar di seantero dunia. Dari sudut pandang Islam, hal ini bisa dikatakan sebagai cobaan dan musibah yang harus dihadapi oleh manusia. Mitigasi cobaan dan musibah menjadi sangat penting. Dalam Qs. alBaqoroh : 155 disebutkan jenis rupa cobaan antara lain ketakutan, kelaparan, kurangnya harta, kurangnya jiwa (kematian / kesehatan) dan kurangnya buah-buahan (kebutuhan bahan makanan pokok). ${ }^{1}$ Manusia dituntut untuk memiliki kompetensi menghadapi lima jenis musibah sejak dini. ${ }^{2}$ Salah satu komptensi etis yang harus dimiliki adalah sabar.

Baqarah: 155)," Ar-Risalab: Media Keislaman, Pendidikan dan Hukum Islam 18, no. 2 (2020): 350-364.

2 Irfan Afandi, "KOMPETENSI SISWA TENTANG KEBENCANAAN DALAM PEMBELAJARAN AL- 
Di dalam Al-Qur'an menawarkan terminologi konsep sabar dalam menghadapi segala bentuk tantangan dan cobaan. Memang, telah banyak kajian tentang konsep sabar dalam kajian etika Islam; tetapi konsep sabar diaplikasikan dalam dunia wirausaha dan dikaitkan dengan penfsiran Qs. Ali Imron : 200, masih belum ada yang membahasnya. Kosep sabar dalam ayat tersebut berbentuk kata perintah yang dikonsep dalam dua bentuk pecahan morfologis yang berbeda yaitu ishbirun dan shobiruu. Tentunya keduanya tidak bisa dikatakan memiliki makna kata yang sama tetapi memiliki varian makna yang berbeda. ${ }^{3}$ Al-Qur'an yang merupakan kitab suci umat Islam memiliki rahasia dalam setiap susunan redaksinya, nuansa keindahan dan keserasian disemua diksinya.

Artikel ini akan membahas konsep sabar sebagai salah satu etika Islam yang bersumber dari penafsiran al-Qur'an dan dikaitkan dengan pendidikan berwirausaha. Lebih jauh lagi, berwirausaha yang dimaknai sebagai proses mengidentifikasi, mengembangkan dan membawa visi ke dalam kehidupan melibatkan bukan hanya pada masalah etika moral tetapi juga melibatkan inner meaning kehidupan. Sehingga, pendidikan karakter tentang etika-spiritualitas dapat menjadi salah satu komptensi bagi peserta didik. Sebab, spiritualitas dalam wirausaha berbicara tentang kemampuan untuk melihat dan membayangkan masa depan yang mungkin tidak dilihat sekaligus diyakini oleh orang lain dapat ditanamkan sejak dini. ${ }^{4}$ Etika-spiritualitas ini dapat menjadi kekuatan dan daya dorong bagi para calon-calon wirausahawan.

Berdasarkan latar belakang tersebut, kajian ini bertujuan untuk menggambarkan dan menganalisis konsep sabar sebagai etika Islam dalam konteks pendidikan berwirausaha. Lebih lanjut lagi, bagaimana etika-spiritualitas Islam dapat manjadi wasilah kekuatan bagi manusia untuk mau berwirausaha. Dua aspek kajian tersebut bersumber berdasarkan analisa penafsiran-penafsiran Qs. Ali Imron : 200.

\section{Perumusan Masalah}

Berdasarkan latar belakang, maka perumusan masalah dalam penelitian ini sebagai berikut :

QUR'AN," INCARE, International Journal of Educational Resources 2, no. 1 (2021): 115-129.

${ }^{3}$ Ahmad Fawaid, "Kaidah Mutarâdif Al-Alfâz Dalam AlQur'an," Mutawatir: Jurnal Keilmuan Tafsir Hadith 5, no. 1 (2015): 142-157.
1. Bagaimana konsep sabar sebagai etika Islam dalam konteks pendidikan berwirausaha berdasarkan tafsir Qs. Ali Imron : 200?

2. Bagiamana integerasi nilai spiritual dalam pendidikan karakter berdasarkan tafsir Qs. Ali Imron : 200?

\section{Tujuan Penelitian}

Berdasarkan perumusan masalah di atas tujuan penelitian sebagai berikut :

1. Mendeskripsikan dan menjelaskan konsep sabar sebagai etika Islam dalam konteks pendidikan berwirausaha berdasarkan tafsir Qs. Ali Imron : 200.

2. Mendeskripsikan dan menjelaskan integerasi nilai spiritual dalam pendidikan karakter berdasarkan tafsir Qs. Ali Imron : 200

\section{Metode Penelitian}

Kajian Qur'an ini berjenis tafsir tematik yang dapat digolongkan sebagai penelitian kepustakaan atau library research. Obyek kajiannya berkenaan tentang Qs. Ali Imron : 200, sedangkan subyek kajiannya mengenai pemaknaan sabar sebagai etika Islam yang dikaitkan dengan kewirausahaan. Sumber pengetahunnya bersumber dari riwayah dan ro'yi yang dikumpulkan melalui penelusuran kitabkitab tafsir. Sedangkan sumber pengetahuan/data yang bersifat ro'yi didasarkan analisa kebahasaan dan kesejarahan. Makna kata sabar akan dianalisia melalui kajian shorfiyah atau ilmu tentang perubahan kata dasar menjadi kata lainnya yang memiliki makna berbeda.

\section{KERANGKA KONSEPTUAL}

\section{Pendidikan Karakter}

Pengertian karakter diartikan sebagai tabiat; sifat-sifat kejiwaan, akhlak atau budi pekerti yang membedakan seseorang dengan yang lain; watak. Karakter sebagai watak diartikan sebagai sifat batin manusia yang mempengaruhi segenap pikiran dan perbuatannya. Sedangkan karakter sebagai watak diartikan sebagai sifat-sifat kejiwaan, budi pekerti atau akhlak yang membedakan manusia satu dengan yang lainnya. Sehingga, karakter manusia merupakan gambaran keseluruhan nilai-nilai, pemikiran, perkataan, dan perilaku atau perbuatan yang akan dan telah

\footnotetext{
${ }^{4}$ Jozef Richard Raco and Rafael H M Tanod, "The Phenomenological Method in Entrepreneurship," International Journal of Entrepreneurship and Small Business 22, no. 3 (2014): 276-285.
} 
membentuk diri manusia. Menurut Purnamasari karakter sebagai sebuah aspek kepribadian akan menjadi cerminan kepribadian utuh dari mentalitas, sikap, dan perilaku seseorang.

Manusia pada dasarnya berkemungkinan memiliki karakter baik sekaligus buruk. Sisi karakter manakah yang akan berkembang paling dominan, itu tergantung dengan perkembangan dalam proses kehidupanya. Ketika karakter sudah pada bentuk perilaku merupakan hasil perpaduan antara karakter bawaan dengan hasil interaksi dengan lingkungan. Instrumen pengembangan karakter baik dalam diri manusia dapat dibentuk melalui pendidikan. Pendidikan dipercaya dapat menjadi alat yang paling efektif untuk memberikan proses penyadaran manusia dalam jati diri asali kemanusiaan. Pendidikan menjadi sebuah proses aktivitas yang disengaja untuk membentuk, mengarahkan dan mengatur manusia sebagaimana dicita-citakan masyarakat

Dalam hal ini, pendidikan merupakan aktiftas yang dihadapkan sebuah tugas untuk memperkenalkan konsekwensi kongkrit kepada peserta didik yang (besuknya) akan menjadi pengalaman hidup. Khazanah pendidikan Islam memperkenalkan beberapa istilah pendidikan yang diambil dalam al-Qur'an antara lain, pertama tarbiyah atau sebuah upaya atau rencana pendampingan untuk mengembangkan potensi anak dimulai sejak dini agar si anak mampu bertahan (survive) dalam kehidupannya kelak. Kedua, ta'lim merupakan upaya pendidikan agar peserta didik mampu mengetahui dan memahami sehingga dapat mengamalkan amal shalih yang bermanfaat di dunia dan akhirat; ketiga, ta'dib merupakan proses pendidikan yang menanamkan, membina dan mengokohkan perilaku peserta didik yang disesuakan dengan syar'iat Islam untuk mencapai ridha Allah SWT; dan keempat yakni tazkiyah yakni usaha pendidikan yahg bertujuan penyucian jiwa manusia dengan memperbaiki ucapan dan perbuatannya. ${ }^{5}$

Konsep tentang pendidikan karakter sudah disadari menjadi hal penting bagi kemanusiaan. Fenomena banyaknya kasus korupsi di pemeritahan negara kita ini disebabkan kurang berkembangnya karakter baik dalam diri manusia. Pendidikan karakter menjadi sebuah upaya yang terencana dan sungguh-sungguh untuk membantu seseorang memahami, peduli, dan bertindak dengan landasan inti nilai-nilai etis. Pendidikan karakter mengacu kepada serangkaian

\footnotetext{
${ }^{5}$ Mikyal Hardiyati and Umi Baroroh, "Tujuan Dan Materi
} Pendidikan Dalam Perspektif Al-Quran (Studi Tafsir pendidikan sikap (attitude), perilaku (behavior), motivasi (motivation) dan keterampilan (skill) manusia.

\section{Nilai Spiritual Islam}

Nilai atau value, secara leksikal adalah sesuatu yang berguna bagi manusia. Apabila dikaitkan dengan sebuah satu aturan tertentu, nilai menjadi standar perbuatan baik dan standar sikap yang menentukan eksistensinya, bagaimana cara pangan terhdap kehidupan dan bagaimana memperlakukan orang lain. Nilai akan selalu berhubungan dengan kebaikan, kebijakan, keluhuran akal budi manusia. Sehingga value sendiri diartikan sebagai penilaian seseorang tentang apa yang penting dalam hidup dan merupakan prinsip atau standar perilaku seseorang. Nilai merupakan prinsip atau standar perilaku yang dapat menyempurnakan manusia sesuai dengan fitrahnya. Prinsip dan standar itu beragam seperti apabila dirangkai dengan keagamaan, nilai memiliki arti konsep prinsip atau standar perilaku dalam kehidupan sakral keagamaan yang menjadi pedoman bagi tingkah laku keagamaan warga masyarakat bersangkutan.

Sedangkan spiritual secara leksikal dalam kbbi.web.id berarti jiwa, roh atau sesuatu yang berhubungan dengan jiwa dan roh. Dalam kajian akademik, spiritual dimaknai sebagai apa yang dibutuhkan oleh roh dan jiwa manusia. Dalam pengertian keagamaan, roh dan jiwa manusia sangat berhubungan dengan Tuhan Yang Maha Esa dan Tuhan Yang Maha Kuasa. Dialah sang pencipta manusia dan alam semesta. Hubungan antara roh dengan yang menciptakan kebutuhan yang harus diatur dalam skema yang disebut sebagai spiritualitas. Dengan konsep spritualitas ini, manusia memahami apa yang paling urgen/penting dan mendasar bagi mereka; sehingga, spiritualitas atau kebutuhan ruhaniyah ini mengatur, memimpin dan mempengaruhi bagaimana cara berfikir, bagaimana berperilaku dan berkegiatan. Oleh karenanya, spiritual ini juga telah dihubungkan dengan kecerdasan manusia yang dissebut dengan kecerdasan spiritual yang maksudnya adalah kemampuan untuk memberi makna dalam semua aktifitas dan perilaku mansuai sebagai hubungan penghambaan antara manusia dengan Penciptanya.

Apabila digabungkan nilai spiritual dapat diartikan sebagai standard perbuatan dan sikap

Tarbawi Karya Ahmad Munir)," JURNAL PENELITLAN 13, no. 1 (2019): 97-122. 
baik yang berdasarkan kebutuhan ruhaniyah yakni kebutuhan untuk selalu tersambung dengan penciptanya. Spiritual ini dapat menyempurnakan eksistensi manusia. Oleh karenanya, nilai spiritual merupakan nilai tertinggi dan bersifat mutlak, karena bersumber dari sang pencipta yang dianggap sebagai kendali dalam memilih kehidupan yang baik dan buruk.

Aspek-aspek spiritaulitas atau keagamaan, menurut Burkhardt yakni semua hal yang berkaitan dengan sesuatu yang tidak diketahui atau ketidakpastian dalam kehidupan; spirtualitas juga sebuah upaya untuk menemukan makna tujuan hidup; dan spiritualitas juga mengajak untuk menyadari bahwa kesuksesan bisa bersumber dari kekuatan dalam diri sendiri. ${ }^{6}$

Kajian spiritualitas Islam ditujukan untuk mendapatkan jiwa yang tenang. Hal ini dijelaskan dalam QS. al-Fajr : 27-30, Allah SWT berfirman :

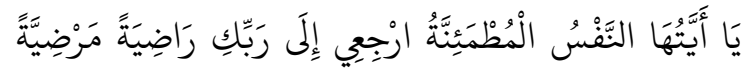

$$
\begin{aligned}
& \text { فَاذْخُلِي فِي عِبَادِي وَادْخُلِي جَنَّتِي }
\end{aligned}
$$

Artinya: Wabai jiwa yang tenang! Kembalilab kepada Tubanmu dengan bati yang ridha dan diridhaiNya. Maka masuklab ke dalam golongan hamba-hamba-Ku, dan masuklah ke dalam surga-Ku.

Tafsir Jalalain menafsirkan kata muthmainnah sebagai orang-orang yang beriman. ${ }^{7}$ Ibn Kastir dengan mengutip pendapat adh-Dhuhak menjelaskan bahwa latar belakang dari ayat ini terkait dengan sahabat Usman ibn Affan; dalam riwayat lain disebutkan ayat ini berkaitan dengan Hamzah ibnu Abdul Muttalib. ${ }^{8}$

Dalam khazanah pemikiran Islam, Sayyed Hosain Nasr berpendapat bahwa spiritual selalu dikaitkan dengan dunia ruh, kedekatan dengan Allah SWT, mengandung kebatinan dan integritas yang disamakan dengan yang hakiki. ${ }^{9}$ Sama halnya dengan pendapat tersebut, proses spiritualitas yang merupakan pengerahan potensi ruhaniyah di dalam diri manusia untuk tunduk dan patuh pada ketentuan syari'at Islam. Ketundukan dan kepatuhan ini digunakan untuk melihat realitas, baik dalam lahir maupun batin.

\footnotetext{
${ }^{6}$ Helmut Burkhardt, "Spirituality and Ethics.," European Journal of Theology 19, no. 1 (2010), 26.

7 Jalaluddin As-Suyuthi and Jalaluddin Al-Mahalli, Tafsir Jalalain, (Surabaya: Imaratullah, 2003), 299.

8 Ibnu Katsir, Tafsir Ibnu Katsir Jilid 1-7, (Beirut: Daar Ma'rifah, 2003), 45

${ }^{9}$ Seyyed Hosein Nasr, Ensiklopedi Tematis Spiritualitas Islam, (Bandung: Mizan, 2002), 67.
}

Pencapaian tingkatan spiritual ini dilakukan dengan cara menjaga nilai-nilai spiritual dalam diri. Pada dunia tasawuf terdapat maqomat di hadapan Allah SWT. Hal ini dapat dicapai melalui pendakian rohaniyah dengan mempertahankan ke-ajeg-kan (istiqomah) baik dalam bentuk peribadatan maupun dari sudut pandang terhadap dunia hanya untuk Allah SWT. Contoh tentang hal ini seperti yang dilakukan Syaikh Zainuddin al-Ma'bari al-Mallibari, pengarang kitab Hidayatul Atqiyaa' Fi Thariqil Auliya menyusun sembilan washoya yang dapat dimasukkan dalam nilai-nilai spiritual untuk mencapai maqom kewaliyan yakni : taubat, qonaah, zuhud, belajar ilmu syariat, melaksanakan kesunahan, tawakal, ikhlas, 'u₹lah dan menjaga waktu. ${ }^{10}$

\section{Kewirausahaan}

Wirausaha berasal dari dua kata yakni wira dan usaha. Wira memiliki arti pahlawan, sifat jantan atau perwira; sedang usaha berarti kegiatan dengan mengerahkan tenaga, pikiran, atau badan untuk mencapai suatu maksud; pekerjaan (perbuatan, prakarsa, ikhtiar, daya upaya) untuk mencapai sesuatu. ${ }^{11}$ Kata wirausaha dalam KBBI.web.id tidak dikenali tetapi dipadankan dengan kata wiraswasta yang berarti orang yang pandai atau berbakat mengenali produk baru, menentukan cara produksi baru, menyusun operasi untuk pengadaan produk baru, memasarkannya, serta mengatur permodalan operasinya. Walaupun begitu, ada pendapat yang memberi penekanan yang berbeda antara wirausaha dan wiraswasta. Wirausaha lebih condong pada usaha dengan bisnis sendiri; tetapi wiraswasta bisa dilakukan dengan bekerja kepada orang lain atau usaha yang dimiliki orang lain.

Rusdiana menyamakan istilah wirausaha dengan entrepreneur. ${ }^{12}$ Pemaknaan ini membawa pengertian seorang entrepreneur adalah orang yang berani menanggung resiko; orang yang menciptakan dan mengurus perusahaan; orang yang menggerakkan dan membelanjakan modal; dan orang yang mampu menciptakan barang baru sehingga memberikan penambahan nilai dari barang tersebut. Pengambilan resiko bukan berarti membuat seorang entrepreneur tidak

${ }^{10}$ S B Al Makki, Kifayatul Atqiya, (Surabaya: Al Hidayah, n.d.), 54.

11 A Rusdiana, Kewirausabaan: Teori Dan Praktek (Yogyakarta: Pustaka Setia, 2018), 98.

12 A Rusdiana, Kewirausabaan: Teori Dan Praktek (Yogyakarta: Pustaka Setia, 2018), 98-100. 
memikirkan resiko tetapi mampu mengatur resiko untuk mendapatkankan untung dari usaha tersebut. Setiap usaha terdapat di dalamnya ketidakpastian, seorang entrepreneur berani mengolah ketidakpastian tersebut menjadi peluang usaha. Mereka menebarkan visi ke depannya kepada orang lain. Makna entrepreneur dalam bentuk proses adalah kegiatan yang memerlukan semangat yang besar, perilaku, sikap sekaligus kemampuan dalam menangani usaha. Entrepreneur menjadi proses yang mengarah pada upaya menciptakan dan menerapkan cara kerja, teknologi dan produk baru. entrepreneur harus berupaya adanya peningkatan efisiensi dan efektifitas dalam rangka memberikan layanan yang yang terbaik sehingga usaha ini memperoleh keuntungan lebih besar.

Hadis nabi Muhammad SAW yang menjelaskan bagaimana keutamaan wirausaha sangatlah banyak di antaranya yang diriwayatkan oleh Imam Bukhori, bahwa nabi Muhammad SAW bersabda :

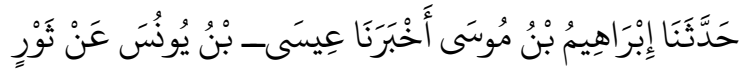

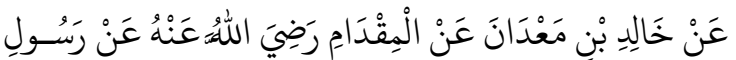

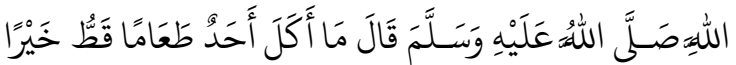

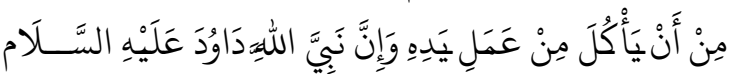

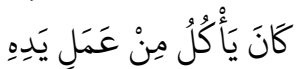

Artinya: Tidaklah seseorang mengkonsumsi makanan yang lebih baik dari makanan yang dihasilkan dari jerih payah tangannya sendiri. Dan sesunggubnya nabi Dand 'alaibissalam dabulu senantiasa makan dari jerih payahnya sendiri (HR. Bukhori).

Hadis tersebut menjelaskan tentang keutamaan tentang berusaha untuk mencukupi makanan dengan berusaha. Istilah 'amali yadihi atau jerih payah tangan sendiri dapat dimaknai dalam konteks wirausaha. Pemakaian kata yadun (secera literal diartikan sebagai tangan) dapat dimaknai secara majasy sebagai kemampuan yang dimiliki diri sendiri. Kemampuan diri ini berasal dari manifestasi dari sikap mental yang dimiliki seorang dalam melaksanakan usaha/kegiatan. ${ }^{13}$

\section{HASIL DAN PEMBAHASAN}

\section{Redaksi QS. Ali Imron : 200}

Allah SWT berfirman :

13 James Arthur Finch Stoner, R Edward Freeman, and Daniel R Gilbert, Management, Pearson Education India, 1995), 78.

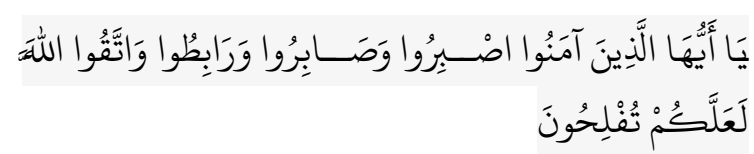

Artinya: Wabai orang-orang yang beriman! Bersabarlah kamu dan kuatkanlah kesabaranmu dan tetaplah bersiap-siaga (di perbatasan negerimu) dan bertakwalah kepada Allah agar kamu beruntung.

Ayat tersebut, secara teoritis, merupakan ayat madaniyah (diturunkan di kota Madinah) yang dilihat dari teori subyektif dalam kajian makkiyahmadaniyyah (aș-Șāliḥ, 2005); hal ini terlihat bahwa mukhothob dari ayat tersebut adalah orang-orang yang beriman; merujuk pada mukmin Madinah. Walapun secara subyektif diturunkan untuk mu'min Madinah tetapi sebenarnya juga diturunkan kepada semua orang mu'min sampai sekarang. Sehingga, apabila ada perintah atau larangan dari ayat Madinah juga diperuntukkan kepada semua orang mu'min.

Ada beberapa kosakata kunci dalam ayat tersebut yang akan dijelaskan sebagai berikut ;

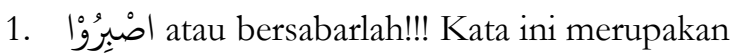
kata yanga berbentuk fi'il amr atau kata kerja dengan obyek perintah plural (orang banyak). Kata dasar dari kata ini berbentuk tsulasti mujarod atau kata kerja yang terdiri dari tiga (3) huruf asli. Susunan huruf dalam kata ini adalah huruf shot, $b a^{\prime}$ dan $r a^{\prime}$ yang merupakan huruf asli sebagai pencirian yang khas sebagai fi'il stulasti mujarod. Huruf alif merupakan huruf ziyadah (tambahan) sebagai sintax dari bentuk kata kerja perintah (fi'il amr); sedangkan huruf wawu dan alif merupakan huruf riyadah untuk menunjukkan obyek jama' / plural yang tereferensikan pada obyek атапии.

2. صَابِرُوْا yang diterjemahkan 'bersabarlah'. Kata ini juga berbentuk fi'il amr dengan obyek jama'/plural. Berbeda dengan kata pertama yang memakai bentuk fi'il stulasti mujarod, kata kedua ini memakai bentuk kata dasar fi'il stulasti maziid (kata kerja tiga huruf dengan tambahan). Huruf dasar dari kata ini adalah huruf shot, $b a^{\prime}$ dan $r a^{\prime}$ 'dengan tambahan huruf alif setelah huruf shot atau secara teknis disebut ziyadah ba'da fa' fi'il (tambahan setalah huruf $f a^{\prime} f i$ 'i $)$. Bentuk morfologis dari kata ini 
memiliki makna salah satunya li takstir atau memperbanyak; sehingga dapat dimaknai memperbanyak sabar; atau juga li ta'diyah (kata kerja yang membytuhkan obyek) sehingga bisa dimaknai bersabarlah terhadap sesuatu.

3. yang diterjemahkan bersiagalah. Kata ini secara sorfiyah memiliki bentuk yang sama dengan kata di atas; yang kemungkinan maknanya adalah memperbanyak bersiaga; kata ini memang diterjemahkan dalam konteks yang berbeda-beda, sebagaimana yang disebutkan oleh Ibn Katsir (Katsir, 2003); dalam konteks berperang 'bersiaga' dimaknai dengan selalu bersiap di pagi hari, sore maupun malam di perbatasan; dalam konteks peribadahan ribath dimakanai dengan memperkuat diri dalam peribadahan; penjelasanan tersebut dalam hadis yang diriwayatkan oleh Muslim dan Nasa'i; Rasulullah SAW mencontohkan ribath sebagai wudhu di waktu yang cuaca dingin, lalu pergi ke masjid dan menunggu untuk menjalankan ibadah sholat berikutnya.

4. وَاتَّتُعــوا اللَّة yang diterjemahkan menjadi bertaqwalah kepada Allah. Takwa (taqwa) berasal dari kata waqa - yaqi - wiqayah yang artinya memelihara yakni menjaga diri dari larangan Allah SWT agar selamat dunia dan akhirat. Jumhur Ulama' memaknai Taqwa secara istilah sebagai 'mengikuti segala perintah-Nya dan menjauhi segala laranganNya' (Imtitsalu awamirillah wajtinabu nawabibi).

5. لَعَلَّكُمْ تُفْلِحُحْونَ yang diterjemahkan menjadi semoga kamu beruntung. Penggunakan kata la'ala menunjukkan adanya kemungkinan besar dan buikan anganan untuk mendapatkan sebuah keberuntungan. Dalam tafsir jalalain, keberuntungan di sini ditafsirkan sebagai mendapatkan surga dan terhindar dari api neraka.

\section{Sabar sebagai Nilai Spiritual}

Sabar (dalam bahasa Indonesia) merupakan kata serapan dari bahasa Arab. Kata sabar dalam web.kbbi.net memiliki arti tahan menghadapi cobaan dan tenang; tidak tergesagesa; tidak terburu nafsu. Terminologi sabar

${ }^{14}$ I A Al-Jauziyah, "Indahnya Sabar: Bekal Sabar Agar Tak Pernah Habis," Jakarta: Maghfirah Utama. Ashy, MA (1999). Health and illness from an islamic perspective. Journal of Religion and Health 38, no. 3, (2007): 241-257. dalam bahasa Arab memiliki tiga makna; pertama, sabar sebagai ash-shobru berarti menahan atau mengurung; kedua, kata ash-shobir dimaknai sebagai obat yang sangat pahit dan tidak disukai orang; dan Ketiga, kata ash-shobr diartikan sebagai menghimpun dan menyatukan ${ }^{14}$. Secara istilah Sabar merupakan upaya menahan untuk tidak gundah dan marah; menahan untuk mengeluarkan keluh kesah, serta menahan anggota tubuh dari perbuatan yang tidak memiliki tujuan.

Qs. Ali Imron : 200, perintah sabar memakai dua kata kerja yang berbeda ishbiruu dan shoobiruu. Ibn Jarir menjelaskan bahwa ada perbedaan antara dua istilah sabar tersebut; mengutib pendapat dari Qotadah memaknai perintah sabar pertama sebagai sabar menjalankan ketaatan kepada Allah SWT dan sabar kedua sebagai sabar menghadapi orang-orang yang berada dalam kesesatan; Ibn Juraiz memaknai perintah sabar pertama sebagai sabar dalam menjalankan ketaatan kepada Allah SWT dan perintah sabar kedua sebagai sabar menghadapi musuh-musuh Allah SWT. Adh-Dhuha' memakanai perintah sabar pertama sebagai sabar menjalankan perintah Allah SWT dan perintah sabar kedua sebagai sabar menghadapi musuh. Ja'far ibn 'Aun memaknai perintah perintah sabar pertama sebagai sabar menjalankkan (perintahlarangan) agama dan perintah sabar kedua sebagai sabar untuk menunggu janji-janji Allah SWT. Zaed ibn Aslam memaknai perintah sabar pertama sebagai sabar melaksanakan jihad dan perintah sabar kedua sabar dalam melawan musuh-musuh ${ }^{15}$.

Secara ilmu bahasa, pemahaman ini berangkat dari ketentuan kaidah shorfiyah di mana perintah sabar pertama berasal dari fi'il stulasti mujarod. Bentuk ini membawa makna laazim di mana kata kerja tersebut tidak membutuhkan obyek dan merupakan fi'il yang menunjukkan sifat yakni sifat sabar. Sehingga, perbedaan pemaknaan yang disebutkan dalam tafsir ath-Thabari lebih menekankan kepada kapan dan di mana sabar tersebut perlu diapliasikan seperti ketika taat kepada Allah SWT, tatkala menjalankan perintah Allah SWT dan melaksanakan jihad. Waktu dan tempat yang disebutkan tersebut merupakan locus dan tempus untuk menjalankan kesabaran.

15 Abu Jaâ Thabari, 'Far Muhammad Ibn Jarir Al', Tafsir Al-

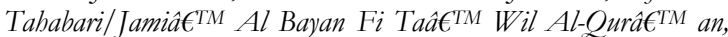
Bairu> t: Dar Al-Kutub Al-Ilmiyyah, 1999. 
Perintah sabar kedua memakai kata kerja berbetuk stulasti majid di mana terdapat penambahan huruf alif setelah $\mathrm{fa}^{\prime}$ fi'il. Ada beberapa fungsi khusus pada wazan (referensi bentuk kata kerja) tersebut. Pemaknaan yang dikutip dalam Tafsir ath-Thabari tersebut mengarahkan kepada fungsi li'ta'diyah atau kata kerja yang mebutuhkan obyek (maf'ul bib). Beberapa pemaknaan kata yang disematkan pada sabar kedua ini menunjukan sabar yang membutuhkan obyek seperti sabar menghadapi orang-orang yang berada dalam kesesatan, sabar menghadapi musuh-musuh Allah SWT, sabar menghadapi musuh-musuh, sabar menunggu janji-janji Allah SWT.

Berbeda dalam terjemah al-Qur'an yang diterbitkan oleh KEMENAG RI dan juga Tafsir Jalalain perintah sabar kedua ini diartikan sebagai usaha untuk terus meningkatkan kesabaran. Artinya, secara kebahasaan fungsi wazan yang digunakan adalah lima'na fa"ala alati litakstir (berfungsi wazan fa"ala dengan makna memperbanyak atau menguatkan. Sehingga, apabila diterjemahkan secara penuh akan berbunyi, "bersabarlah kamu dan kuatkanlah kesabaranmu."

Pemahaman-pemahaman tentang dua perintah sabar merupakan penjelasan tentang kapan manusia menerapkan kesabaran. Untuk Sabar dalam pengertian pertama merupakan keadaan untuk bisa menerima segala macam situasi dan kondisi secara tabah. Sabar merupakan sebuah nilai spritual Islam di mana apabila berada pada posisi mendapatkkan musibah dan cobaan semuanya adalah milik Allah SWT dan akan kembali kepadaNya. Hal ini termaktub dalam Qs. al-Baqoroh : 156, Allah SWT berfirman ;

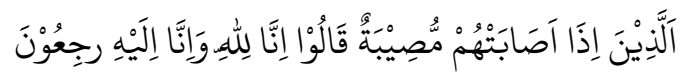

Artinya: (yaitu) orang-orang yang apabila ditimpa musibah, mereka berkata "Inna lillabi wa inna ilaibi raji "un" (sesunggubnya kami milik. Allah dan kepada-Nyalab kami kembali).

Orang sabar adalah orang-orang yang memilliki pemahaman bahwa keseluruhan tersebut merupakan milik Allah SWT dan akan kembali kepada Allah SWT. Dari sudut pandang inilah, sabar sebagai nilai spiritual merupakan pemberian makna bahwa semuanya adalah milik Allah SWT dan kembali kepadaNya.

Sabar dalam pengertian kedua adalah sabar yang membutuhkan ketekunan, fokus, pantang menyerah, tidak terburu-buru/sembrono dan menghadapi kesulitan, berusaha mengatasi masalah dan bekerja keras. Sebab, perintah sabar kedua ini kesabaran ketika menghadapi orang lain. Dalam al-Qur'an disebutkan, Allah SWT berfirman :

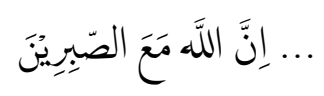

Artinya:..... Allah beserta orang-orang yang sabar.

Sabar, di sini merupakan pemberian makna bahwa orang-orang yang sabar merupakan orangorang yang bersama Tuhan. Dalam tafsir Quraiys shihab disebutkan bahwa maksud dari ayat tersebut adalah Allah SWT akan menjadi pelindung dan penolong orang-orang yang sabar.

\section{Ribath Sebagai Nilai Spiritual}

Perintah ketiga dalam Qs. Ali Imron : 200 di atas adalah robithu atau bersiap siagalah. Ibn Kastir menafsirkan perintah ini dalam dua pemaknaan yakni pertama, dimaknai dalam pengertian peribadahan yakni dalam hadis nabi Muhammad SAW yang berbunyi :

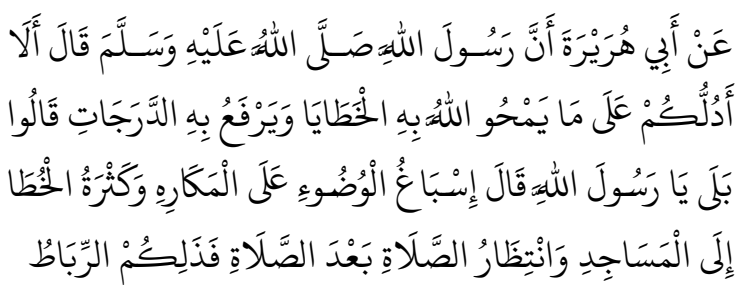

Artinya: Dari abu Hurairah r.a. sesunggubnya Rasululah SAW bersabda "Apakah kalian mau aku tunjukkan amalan yang dapat menghapus dosa dan mengangkat derajat? Mereka menjawab, "Mau, wahai Rasulullah." Rasulullab bersabda, "Menyempurnakan wudbu'pada saat-saat yang tidak disukai, memperbanyak langkah kaki menuju ke masjid, dan menunggu shalat setelah shalat. Yang demikian itulah ar Ribath" (HR. Muslim)

Ribath dalam pengertian ibadah memiliki arti bersungguh-sungguh dalam peribadahan mulai dari menyempurnakan wudhu pada saat cuaca dingin, menuju masjid dan menunggu shalat setelah shalat lain semisal menunggu sholat isya setelah shalat maghrib. Kedua, dalam konteks berjaga-jaga di perbatasan wilayah musuh. Pemaknaan ini dikuatkan dengan hadis yang diriwayatkan oleh Muslim,

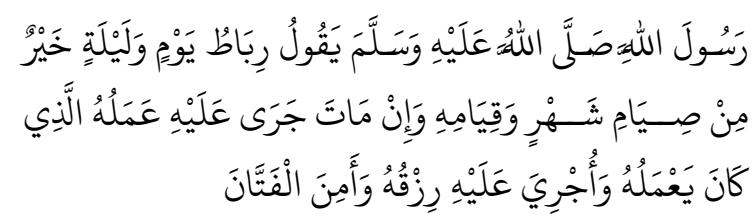


Artinya : Rasulullah SAW bersabda "Orang yang menjaga di tapal batas sehari semalam lebih baik dari puasa dan shalat malam selama sebulan. Dan jika ia mati, maka mengalirlah (pabala) amal yang biasa ia kerjakan, diberikan rizkinya, dan dia dilindungi dari adzab (siksa) kubur dan fitnabnya". (HR. Muslim)

Dua pemaknaan ribath menunjukkan bahwa ribath sebagai nilai spirital memiliki makna tentang sebuah kesungguh-sungguhan yang berdasarkan ilahiyah. Ribath berbicara tentang kesungguhan dalam beribadah yang tidak surut dengan halangan apapun; di sisi lain ribath juga membicarakan tentang penjagaan perbatasan wilayah musuh yang membutuhkan keberanian; perilaku ribath ini disambungkan dengan pahala yang besar, peninggian derajat, menghapus dosa lainnya, kemulyaan hidup di hadapat Tuhan YME dan tentang terhindar dari adzab, siksa dan fitnah kubur. Kesemua itu berhubungan dengan spiritualitas ketuhanan.

\section{Taqwa dan Keberuntungan}

Ibn Jarir mengutip pendapat Ibn abi Ka'ab al-Khuraizy yang memahami taqwa dalam Qs. Ali Imron : 200 sebagai takut kepada Allah SWT agar bisa beruntung dengan dapat menemui Allah SWT. Kartini menginduksikan bahwa Taqwa memiliki tiga komponen relasi; pertama nilai yang berhubungan dengan sang pencipta. Relasi ini merupakan bentuk semangat pengabdian dan penghambaan, keikhlasan dan ketundukan, kepatuhan dan ketaatan kerinduan kepada sang pencipta. Kedua, taqwa juga berkaitan relasi dengan hati nurani sendiri di mana selalu menjaga hati nurani dengan selalu berperilaku baik dan menjauhi perilaku buruk. Dan ketiga relasi dengan sesama manusia. Bentuk relasi ini taqwa termanifestasikan dalam perbuatanperbuatan yang selalu membina hubungan baik dengan sesama manusia.

Taqwa dangat berkaitan dengan kemulyaan, keselamatan kemudahan dan jalan keluar. Hal ini disebutkan dalam Qs. ath-Thalaq 2, Allah berfirman;

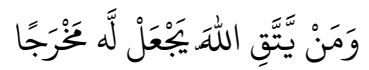

Artinya: Barangsiapa bertakwa kepada Allah niscaya Dia akan membukakan jalan keluar baginya.

Dalam Qs. ath-Thalaq 4, Allah berfirman;

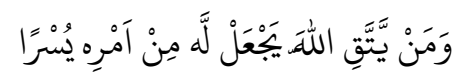

Artinya: Dan barangsiapa bertakwa kepada Allah, niscaya Dia menjadikan kemudahan baginya dalam urusannya.

\section{Integrasi Nilai Spiritual dalam Pendidikan Karakter}

Penjelasan tentang nilai-nilai spiritual yang terdapat dalam Qs. Ali Imron : adalah sabar bentuk 1 dan 2, ribath dan taqwa. Keempat hal ini didudukkan sebagai nilai spiritual yang ditautkan dengan eksistensi sang pencipta untuk mendapatkan keberuntungan dalam kewirausahaan. Empat hal tersebut juga merupakan sikap mental, tabiat dan budi pekerti yang dibutuhkan untuk meraih kesuksesan dan keberuntungan dalam berwirausaha.

Dalam ranah pendidikan, lingkungan pendidikan hendaknya mampu menciptakan kondisi untuk memikirkan nilai moral sabar, ribath, dan taqwa. Tentunya peserta didik juga harus diajarkan bagaimana menghadapi situasi yang menuntut mengaplikasikam kemampuan pengambilan keputusan dalam situasi yang sangat dilematis. Proses pembelajaran ini dilakukan dengan proses indoktrinasi. ${ }^{16}$

Penerapan indoktrinasi yakni dengan cara peserta didik diajarkan untuk menemukan alasan-alasan kongkrit dalam bersabar, ribath dan bertaqwa. Di samping itu, peserta didik juga diajari untuk mengaplikasikan menjadi sebuah tindakan. Penyelarasan pemikiran nilai spiritual dilakukan melalui peningkatan kecerdasan emosional dan spiritual serta pembiasaan. Model pembelajaran yang yang bisa digunakan dalam usaha indoktrinasi nilai-nilai spiritual dalam Qs. Ali Imron : 200 dalam konteks kewirausaan adalah mempergunakan pembelajaran terintegrasi atau model pembelajaran terpadu. Keterpaduan materi diginakan untuk mengkonstruk penanaman nilai atau karakter dalam Qs. Ali Imron : 200 kepada siswa.

Adapun yang dimaksud tentang pembelajaran terintegrasi adalah model pembelajaran yang bertujuan untuk membiasakan pembelajar melihat sesuatu dari berbagai sudut pandang. Pembelajaran diawali dengan satu pokok bahasan lalu dikaitakan dengan materi lainnya sehingga materi akan lebih bermakna. ${ }^{17}$

\footnotetext{
${ }^{16}$ Darmiyati Zuchdi, Humanisasi Pendidikan, Jakarta: Bumi Aksara, 2010), 45.
} 
Fogarty menyatakan bahwa model pembelajaran teradu ada sepuluh. ${ }^{18}$ Trianto menyederhanakan model Fogarty dalam 2 macam model, ${ }^{19}$ antara lain :

1. Interdisplin Ilmu dalam pendidikan karakter atau disebut dengan interdisiplinarity merupakan perwujudan antara dua atau lebih bidang ilmu yang dapat beralih dari komunikasi ide-ide sederhana kedalam pengintegrasian konsep-konsep mendasar dalam sebuah pembelajaran. Semisal, pemaknaan Qs. Ali Imron : 200 dapat digunakan untuk materi sifat, karakter dan nilai spiritualitas kewirausahaan. Perintah sabar dengan pengertian kalimat ishbiru dan shobiru, perintah bersiap-siap selalu up to date dalam perintah robithu; serta selalu takut kepada Allah SWT adalah karakter yang dibutuhkan oleh seorang wirausahawan. Dari contoh ini, model ini mengintegrasikan satu konsep-konsep kajian tafsir Qs. Ali Imron : 200 yang ditumbuhkembangkan dalam materi pelajaran ilmu ekonomi atau mata pelajaran kewirasahaan dalam subpokok bahasan karakter nilai spiritual kewirausahaan. Kaitan-kaitan yang dibangun antara konsep dan spiritualitas dalam Qs. Ali Imron : 200 tersebut dapat dilakukan secara spontan atau direncanakan terlebih dahulu.

2. Model pembelajaran terpadu antardisiplin Ilmu yakni pembelajaran yang memadukan konsep atau pokok bahasan disiplin ilmu yang satu dengan disiplin ilmu lainnya. Dalam prakteknya, pembelajaran model ini menggabungkan bidang studi dengan cara menetapkan proritas kurikuler dan menemukan konsep, keterampilan, dan sikap yang saling tumpah tindih. Dalam konteks ini, materi kesuksesan berwirausaha membutuhkan konsep tentang jiwa kewirausaan, antara lain kreatif dan berani, kemauan kuat dan semangat yang tinggi, memiliki jiwa kepemimpinan dan totalitas. Materi tentang jiwa yang dibutuhkan untuk menjamin kesuksesan berwirausaha dapat diambil dari penafsiran Qs. Ali Imron : 200. Seorang pengajar atau tim pengajar (team teaching) menjelaskan tentang karakter wirausaha lalu dikaitkan dengan nilai-nilai spiritualitas dalam ayat al-Qur'an tersebut. Seorang wirausaha yang sukses apabila menjalankan perintah sabar dengan

18 Robin Fogarty, The Mindful School: How To Teach for Metacognitive Reflection. (ERIC, 1994), 12. pengertian kalimat ishbiru dan shobiru, perintah bersiap-siap selalu up to date dalam perintah robithu; serta selalu bertaqwa kepada Allah SWT.

\section{SIMPULAN}

Adapun yang dimaksud tentang pendidikan kewirausahaan menjadi pembelajaran yang penting di era sekarang ini. Perkembangan teknologi, wabah penyakit dan bencana alam menjadi tantangan bagi umat manusia dalam berwirausaha. Pendidikan adalah salah satu cara dalam persiapan menghadapi tantangan era disrubsi ini. Materi-materi yang bersifat profan harus dipadukan dengan materi-materi yang bersifat sakral. Qs. Ali Imron : 200 dapat digunakan untuk menjelaskan bagaimana sosok wirausaha yang sukses di era disrubsi ini. Kwalitas tentang sabar dengan pengertian kalimat ishbiru dan shobiru, perintah bersiap-siap selalu up to date dalam perintah robithu; serta selalu takut kepada Allah SWT merupakan nilai-nilai spiritual yang dapat menjadi dasar berwirausaha.

Dalam konteks pendidikan karakter, strategi dan model penyampaian yang bisa digunakan untuk mengaitkan antar dua hal yang berbeda tersebut dengan cara pembelajaran terintegrasi atau pembelajaran terpadu. Terdapat dua pola pembelajaran terdapadu untuk menyampaikan materi Qs. Ali Imron : 200 dalam konteks kewirausahaan; pertama, interdisiplin yakni memadukan pokok bahasan, konsep, keterampilan, atau nilai-nilai dalam masingmasing disiplin ilmu. Kedua, antardisiplin ilmu yakni memadukan konsep atau pokok bahasan disiplin ilmu yang satu dengan disiplin ilmu lainnya.

\section{DAFTAR RUJUKAN}

Afandi, Irfan. "KOMPETENSI SISWA TENTANG KEBENCANAAN DALAM PEMBELAJARAN AL-QUR'AN." INCARE, International Journal of Educational Resources 2, no. 1 (2021): 115-129.

Afandi, Irfan, and M Amir Mahmud. "STRATEGI MENGHADAPI COBAAN DALAM AL-QUR'AN (Pemaknaan Tekstual Dan Kontekstual Terhadap Qs. Al-Baqarah: 155)." Ar-Risalab: Media Keislaman, Pendidikan dan Hukum Islam 18, no. 2 (2020): 350-364.

Al-Jauziyah, I A. "Indahnya Sabar: Bekal Sabar

19 Trianto Trianto, Model Pembelajaran Terpadu, (Jakarta: Bumi Aksara, 2010), 25 
Agar Tak Pernah Habis." Jakarta: Maghfirah Utama. Ashy, MA (1999). Health and illness from an islamic perspective. Journal of Religion and Health 38 (2007): 241-257.

As-Suyuthi, Jalaluddin, and Jalaluddin Al-Mahalli.

"Tafsir Jalalain." Surabaya: Imaratullab (2003).

Bukhari, I. "Sahih Bukhari,” 1986.

Burkhardt, Helmut. "Spirituality and Ethics." European Journal of Theology 19, no. 1 (2010).

Fawaid, Ahmad. "Kaidah Mutarâdif Al-Alfâz Dalam Al-Qur'an." Mutawatir: Jurnal Keilmuan Tafsir Hadith 5, no. 1 (2015): 142157.

Fogarty, Robin. The Mindful School: How To Teach for Metacognitive Reflection. ERIC, 1994.

Hardiyati, Mikyal, and Umi Baroroh. "Tujuan Dan Materi Pendidikan Dalam Perspektif Al-Quran (Studi Tafsir Tarbawi Karya Ahmad Munir)." JURNAL PENELITIAN 13, no. 1 (2019): 97-122.

Katsir, Ibnu. “Tafsir Ibnu Katsir Jilid 1-7.” Beirut Lebanon: Daar Ma'rifab (2003).

Al Makki, S B. "Kifayatul Atqiya." Surabaya: Al Hidayah (n.d.).

Nasr, Seyyed Hosein. "Ensiklopedi Tematis Spiritualitas Islam, Terj." Rahmani Astuti, Mizan, Bandung (2002).

Raco, Jozef Richard, and Rafael H M Tanod. "The Phenomenological Method in Entrepreneurship." International Journal of Entrepreneurship and Small Business 22, no. 3 (2014): 276-285.

Rusdiana, A. "Kewirausahaan: Teori Dan Praktek.” Pustaka Setia, 2018.

Stoner, James Arthur Finch, R Edward Freeman, and Daniel R Gilbert. Management. Pearson Education India, 1995.

Subroto, Hadi. "Pembelajaran Terpadu, Materi Pokok PGSD." Universitas Terbuka, Jakarta (2000).

Thabari, Abu Jaâ. "Far Muhammad Ibn Jarir Al." Tafsir al-Tahabari/Jamiâ€€TM al bayan fi Taấ $\epsilon^{T M}$ wil al-Qurât ${ }^{T M}$ an, Bairu> t: Dar al-Kutub alIlmiyyah (1999).

Trianto, Trianto. "Model Pembelajaran Terpadu." Jakarta: Bumi Aksara (2010).

Zuchdi, Darmiyati. "Humanisasi Pendidikan
(Edisi Ketiga)." Jakarta: Bumi Aksara (2010). 